\title{
Diagnostic Study of a Synthetic Human Corticotropin- Releasing Hormone (hCRH) in Healthy Adult Males: Its Plasma Pharmacokinetics and the Effects on the Urinary Excretion of Steroid Hormones
}

\author{
Koshi TANAKA, Megumi NAGATA, Sachiko ITOH, \\ Munehito KUMAGAE ANd NaOKata SHIMIZU \\ Third Department of Medicine, Teikyo University School of \\ Medicine, Ichihara 299-01, Japan
}

\begin{abstract}
The pharmacokinetics, responses of plasma ACTH and cortisol, urinary excretion of steroid hormones, and safety of MCI-028, a synthetic human corticotropin-releasing hormone (hCRH), were examined in eight healthy adult male volunteers after intravenous administration of 33, 100 and $200 \mu \mathrm{g}$ of the drug. The disappearance of MCI-028 from plasma could be fitted to a biexponential decay curve, the plasma half-lives $\left(\mathrm{T}_{1 / 2}\right)$ were 0.12 to $0.15 \mathrm{~h}$ for $\alpha$ phase, and 0.57 to $0.67 \mathrm{~h}$ for $\beta$ phase. Plasma ACTH and cortisol concentrations and the urinary excretion of steroid hormones (particularly free cortisol) increased significantly in relation to the MCI-028 dose administrated. Although hot flushing and an increase in the heart rate were observed at higher doses, they were mild and transient. It is also considered that the urinary excretion of free cortisol after the administration of MCI-028 can be an index reflecting the functioning of this system.
\end{abstract}

Key words: hCRH, Healthy adults, Hypothalamic-pituitary-adrenocortical system, Diagnostic drug, Safety.

(Endocrine Journal 40: 591-596, 1993)

SINCE HARRIS [1] suggested that hypothalamic hormones may regulate the secretion of anterior pituitary hormones, many investigators have directed their efforts to the isolation of corticotropin-releasing hormone (CRH), one of the hypothalamic hormones, and the elucidation of its chemical structure. Although this work was difficult, because CRH exists in the hypothalamus only in trace amounts, Vale et al. [2] succeeded in isolating and identifying of ovine CRH (oCRH) in 1981. Their report showed that CRH has the structure of a single chain polypeptide consisting of 41 amino acids, whose $\mathrm{C}$ terminal is amidated. Additionally, in 1983, Shibahara et al. [3] showed

Received: January 7, 1993

Accepted: August 5, 1993

Correspondence to: Dr. Koshi TANAKA, Third Dept. of Medicine, Teikyo University School of Medicine, 3426-3 Anesaki, Ichihara city, Chiba 299-01, Japan that the structure of human $\mathrm{CRH}(\mathrm{hCRH})$ is identical to rat $\mathrm{CRH}$ [4] and different from oCRH in 7 amino acids.

Many clinical studies have been conducted since the structure of CRH was elucidated; it has been confirmed that CRH causes no significant adverse reaction $[5,6]$ and selectively stimulates the secretion of ACTH by acting directly on the ACTH secretory cells in the anterior lobe of the pituitary [7]; and the usefulness of pituitary ACTH secretory function as a diagnostic drug has been shown $[5,6,8]$. But there are few reports concerning the pharmacokinetics of hCRH and the urinary excretion of steroid hormones in humans.

In the present study, after intravenous administration of an hCRH preparation (code number MCI-028), synthesized at Mitsubishi Kasei Corporation, to healthy adult male volunteers, changes in the plasma hCRH concentration, plasma ACTH and cortisol concentrations, urinary 
excretion of steroid hormones, production of antibody and safety were examined.

The findings obtained are reported as a phase I clinical study of MCI-028.

\section{Subjects and Methods}

\section{Subjects}

This study was performed from February, 1990 to September, 1990 at Teikyo University Hospital after approval of the Ethical Committee and Institutional Review Board.

Eight healthy male volunteers aged from 23 to 38 years (mean 28.8 years) and weighing 57.8 to $68.0 \mathrm{~kg}$ (mean $62.7 \mathrm{~kg}$ ) were selected. They were negative in the MCI-028 intradermal reaction test (intradermal administration of $0.01 \mu \mathrm{g}$ ). Before starting the study, all subjects were informed, by the physicians in charge, of the purpose and method of the study, the expected effect and risk, that it would not be detrimental to them even if they did not agree to participate in the study, that they could withdraw at any time even after agreeing to participate in the study, and of other requirements concerning protection of human rights, and they gave their written consent.

\section{Dose of $h C R H$}

Subjects were randomly assigned to 2 groups; to one group $(\mathrm{n}=4), 33 \mu \mathrm{g}, 100 \mu \mathrm{g}$, placebo and 200 $\mu \mathrm{g}$ were administered and placebo, $33 \mu \mathrm{g}, 100 \mu \mathrm{g}$ and $200 \mu \mathrm{g}$ to another group $(\mathrm{n}=4)$ once each in order. The interval of administration of MCI-028 was 18 to 24 days, and the study was conducted by a single blind method in which subjects are not informed of the dose.

\section{Method of administration}

The drug used was a lyophilized injection containing $100 \mu \mathrm{g}$ of MCI-028 in 1 vial, dissolved in $3 \mathrm{~m} l$ of physiological saline immediately prior to injection, and intravenously administered at the given dose.

The study was started after an overnight fast in the early morning after allowing the subjects to rest quietly for more than $30 \mathrm{~min}$. The subjects had to remain quiet in bed until the end of the examination $4 \mathrm{~h}$ after the drug administration and, if possible, until the end of the examination $24 \mathrm{~h}$ after administration.

Determination of the plasma concentrations of $h C R H$, ACTH and cortisol

The blood was withdrawn at 30 and $15 \mathrm{~min}$ before, immediately before, $5,10,15,30,45,60$, $90,120,240,480 \mathrm{~min}$ and $24 \mathrm{~h}$ after administration, and the EDTA plasma was obtained, frozen and stored until assayed. The hCRH concentration was determined by radioimmunoassay (RIA) according to the method of Toyama et al. [9] at Mitsubishi Yuka Bio-Clinical Laboratories, Inc.

Plasma ACTH and cortisol concentrations were determined by RIA at the Central Laboratory Department, Teikyo University Hospital with a Mitsubishi Yuka ACTH IRMA kit (Mitsubishi Petrochemical Co., Ltd.) and an Eiken cortisol RIA kit (Eiken Kagaku Co., Ltd.), respectively.

\section{Determination of urinary hormone concentration}

Complete urination was conducted immediately before administration, and the urine was collected at $4 \mathrm{~h}$ after administration and used as the sample for determination. 17-Hydroxycorticosteroid (17OHCS) and 17-ketosteroid (17-KS) with colorimetry and free cortisol with RIA were determined at the Central Laboratory Department, Teikyo University Hospital. For calculation, the values found were corrected from the urinary excretion of creatinine.

\section{Production of antibody}

The hCRH antibody in the plasma of each subject before and $24 \mathrm{~h}$ after the last administration (40 to 67 days after the first injection) of MCI-028 $(200 \mu \mathrm{g})$ was examined by the polyethylene glycol sedimentation method at Mitsubishi Yuka Bio-Clinical Laboratories, Inc.

\section{Clinical signs and symptoms}

Clinical signs and symptoms were regularly observed; blood pressure, heart rate, body temperature and respiration rate were determined and electrocardiograms (ECG) were taken with time until $8 \mathrm{~h}$ after drug administration. 


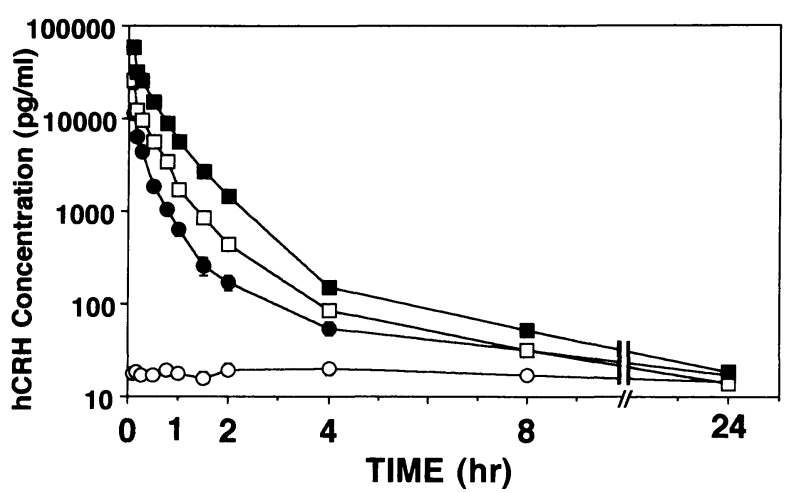

Fig. 1. Disappearance of hCRH from plasma after administration of MIC-028. $\bigcirc, 0 \mu \mathrm{g}$ (placebo);, $33 \mu \mathrm{g}$; $\square$, $100 \mu \mathrm{g} ; \mathbf{\square}, 200 \mu \mathrm{g}$ of MCI-028. Each value is the mean \pm SEM for 8 subjects.

\section{General laboratory tests}

Laboratory tests on general items were performed at $23 \mathrm{~h}$ before and $24 \mathrm{~h}$ after drug administration.

Statistical analysis and analysis of pharmacokinetic parameters

The results were expressed as the mean \pm standard error unless otherwise mentioned. Clinical data were examined with the $5 \%$ significance level by means of the paired $t$-test. The concentration-time data for plasma hCRH till $4 \mathrm{~h}$ after the administration of MCI-028 were fitted to a twocompartment model by a MULTI non-linear minimum square analysis program [10].

\section{Results}

\section{1) Plasma hCRH concentration}

The plasma concentration of hCRH reached 11 , 26 and $60 \mathrm{ng} / \mathrm{ml}$ at $5 \mathrm{~min}$ after the administration of 33, 100 and $200 \mu \mathrm{g}$ of MCI-028, respectively, and quickly decreased to the basal level by $24 \mathrm{~h}$ (Fig. 1). Since basal plasma hCRH did not fluctuate with time after administration of the placebo, the hCRH value before administration was subtracted from the measurement at each time point. The pharmacokinetic parameters such as plasma halflife for the $\alpha$ phase $\left(\mathrm{T}_{1 / 2} \alpha\right)$ and $\beta$ phase $\left(\mathrm{T}_{1 / 2} \beta\right)$, the area under the concentration curve $\left(\mathrm{AUC}_{0}^{\infty}\right)$, the distribution volume ( $\mathrm{Vd})$ and the total clearance (CL) were calculated (Table 1). $\mathrm{T}_{1 / 2} \alpha$ and $\mathrm{T}_{1 / 2} \beta$ were 0.12 to $0.15 \mathrm{~h}$ and 0.57 to $0.67 \mathrm{~h}$, respectively. And there was good linearity between the dose and $\mathrm{AUC}_{0}^{\infty}$.

\section{2) ACTH and cortisol concentrations}

After a single intravenous administration of each dose of MCI-028, plasma ACTH and cortisol concentrations increased significantly and dosedependently (Fig. 2). Plasma ACTH and cortisol concentrations reached their maxima at 15 or 30 min and 30 or $60 \mathrm{~min}$ after administration, respectively, and thereafter quickly decreased. When 33, 100 and $200 \mu \mathrm{g}$ of MCI-028 were administered, the rates of mean maximum increase in the plasma ACTH concentration were $94.3,187.7$ and $165.9 \%$, and those in the plasma cortisol concentration were 55.8, 80.4 and $57.9 \%$, respectively.

Table 1. Pharmacokinetic parameters after administration of various doses of MCI-028

\begin{tabular}{|c|c|c|c|c|}
\hline \multirow[b]{2}{*}{ Parameters } & \multirow[b]{2}{*}{ [unit] } & \multicolumn{3}{|c|}{$\begin{array}{l}\text { Dose of MCI-028 } \\
\text { (number of subjects) }\end{array}$} \\
\hline & & $\begin{array}{l}33 \mu \mathrm{g} \\
(8)\end{array}$ & $\begin{array}{c}100 \mu \mathrm{g} \\
(8)\end{array}$ & $\begin{array}{l}200 \mu \mathrm{g} \\
(8)\end{array}$ \\
\hline $\mathrm{T}_{1 / 2} \alpha$ & {$[\mathrm{h}]$} & $0.15 \pm 0.04$ & $0.15 \pm 0.09$ & $0.12 \pm 0.07$ \\
\hline $\mathrm{T}_{1 / 2} \beta$ & [h] & $0.66 \pm 0.25$ & $0.67 \pm 0.29$ & $0.57 \pm 0.09$ \\
\hline $\mathrm{AUC}_{0}^{\infty}$ & {$[\mathrm{ng} \cdot \mathrm{h} / \mathrm{m} l]$} & $3.67 \pm 0.56$ & $8.80 \pm 1.92$ & $24.74 \pm 2.73$ \\
\hline $\mathrm{Vd}$ & {$[l]$} & $2.48 \pm 0.49$ & $3.98 \pm 1.68$ & $2.58 \pm 0.73$ \\
\hline CL & {$[l / \mathrm{h}]$} & $9.16 \pm 1.36$ & $11.84 \pm 2.53$ & $8.18 \pm 0.96$ \\
\hline
\end{tabular}

$\mathrm{T}_{1 / 2}$, half-life; $\mathrm{AUC}_{0}^{\infty}$, area under the concentration curve; $\mathrm{Vd}$, distribution volume; $\mathrm{CL}$, total clearance. Each measurement is the mean $\pm \mathrm{SD}$ for 8 subjects. 


\section{3) Urinary hormone concentration}

Significant and dose dependent increases in the urinary excretion of free cortisol (with 33, 100 and $200 \mu \mathrm{g}$ dosages of MCI-028), 17-OHCS (with 100 and $200 \mu \mathrm{g}$ ) and $17-\mathrm{KS}$ (with $200 \mu \mathrm{g}$ ) were observed (Fig. 3). The rates of the mean increase in urinary free cortisol following the administration of 33, 100 and $200 \mu \mathrm{g}$ were 78.4, 106.0 and $117.7 \%$, respectively.

\section{4) Production of antibodies}

Both before and after the administration of MCI-028 in all subjects, there was no sign of hCRH antibodies in the plasma.

\section{5) Clinical signs and symptoms}

Facial warmness was observed in 1 case $(12.5 \%)$ and 6 cases $(75.0 \%)$ after the administration of 100 and $200 \mu \mathrm{g}$ of MCI-028, respectively. It was
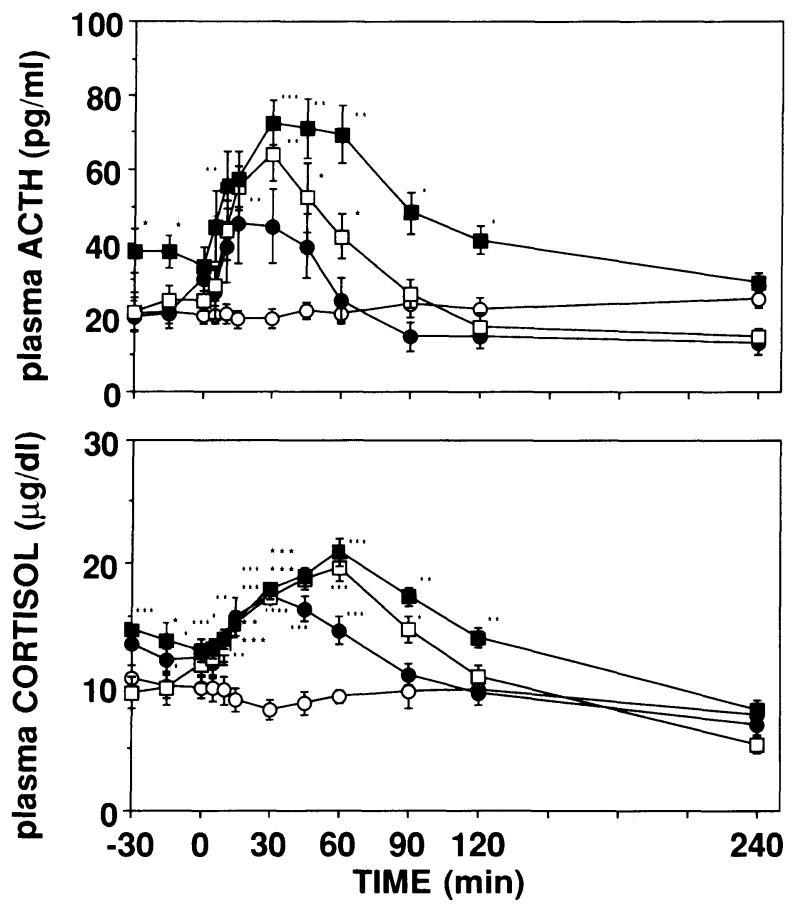

Fig. 2. Responses of plasma ACTH (upper panel) and cortisol (lower panel) after administration of MCI028. $\bigcirc, 0 \mu \mathrm{g}$ (placebo);, $33 \mu \mathrm{g} ; \square, 100 \mu \mathrm{g} ; \mathbf{\square}, 200$ $\mu \mathrm{g}$ of MCI-028. Each value is the mean \pm SEM for 8 subjects. Paired $t$-test was performed for the value following administration of $0 \mu \mathrm{g}$. *, $P<0.05$; **, $P<0.01 ; * * *, P<0.001$. evident in all within 5 min after drug administration and disappeared within $30 \mathrm{sec}$ to $30 \mathrm{~min}$, was mild and did not require treatment. No other abnormality was observed.

6) Effects on blood pressure, heart rate, ECG, body temperature and respiration rate

There was no significant change in blood pressure after the administration of each dose of MCI-028, After the administration of 100 and 200 $\mu \mathrm{g}$ of MCI-028, the heart rate increased (mean maximum of 10 and 17 beats $/ \mathrm{min}$, respectively) and returned to the basal rate within 20 and 120 min (Fig. 4). Throughout the study, no abnormality or significant difference was observed in the ECG, body temperature or respiration rate after the administrations of each dose of MCI-028 or the placebo.

\section{7) Laboratory test values}

No notable abnormality was observed in any subject.

\section{Discussion}

Pharmacokinetic analysis of hCRH has been previously examined by Schurmeyer et al. [11]. They reported monoexponential plasma elimination of $\mathrm{T}_{1 / 2}=0.07 \mathrm{~h}$ after the intravenous administration of $1 \mu \mathrm{g} / \mathrm{kg}$ and biexponential plas-

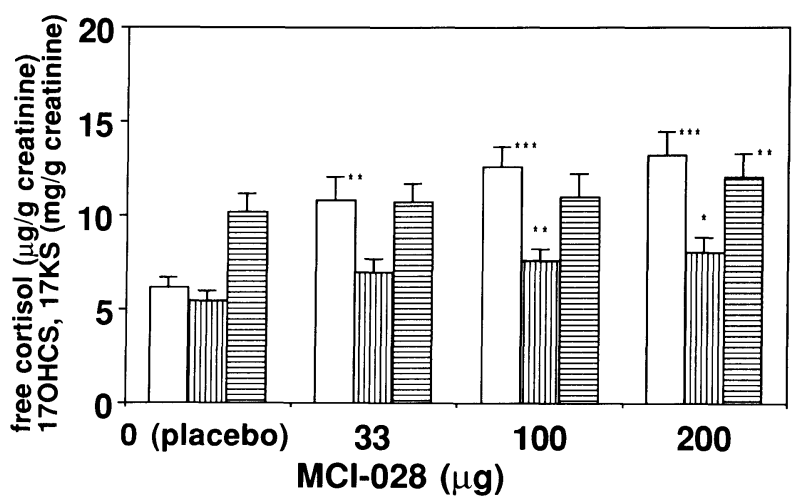

Fig. 3. Urinary excretion of free cortisol ( $\square$ ), 17-OHCS ( $\square$ ) and 17-KS ( $\square$ ) after administration of MCI-028. Each value is the mean \pm SEM for 8 subjects. Paired $t$-test was performed for the value following administration of $0 \mu \mathrm{g}$. *, $P<0.05$; **, $P<0.01$; ***, $P<0.001$. 

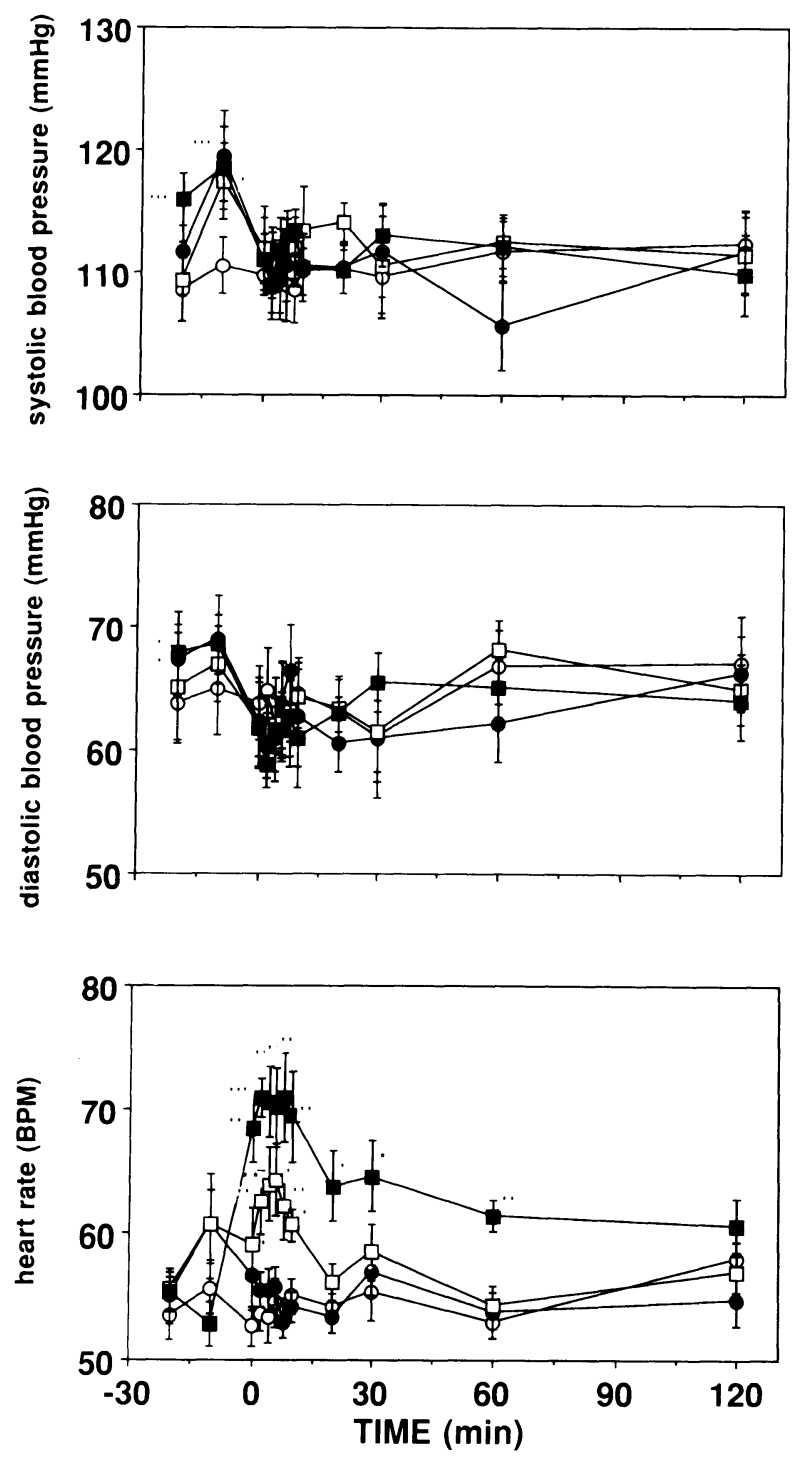

Fig. 4. Systolic blood pressure (upper panel), diastolic blood pressure (middle panel), and heart rate (lower panel) after administration of MCI-028. $\bigcirc, 0 \mu \mathrm{g}$ (placebo); - $33 \mu \mathrm{g} ; \square, 100 \mu \mathrm{g} ; \mathbf{\square}, 200 \mu \mathrm{g}$ of MCI-028. Each vlaue is the mean \pm SEM for 8 subjects. Paired $t$-test was performed for the value following administration of $0 \mu \mathrm{g}$. **: $P<0.01, * * *: P<0.001$. ma elimination of $\mathrm{T}_{1 / 2} \alpha=0.09 \mathrm{~h}$ and $\mathrm{T}_{1 / 2} \beta=$ $0.42 \mathrm{~h}$ after $5 \mu \mathrm{g} / \mathrm{kg}$. In the present experiments with 33 to $200 \mu \mathrm{g}$ of MCI-028 (0.5 to $3.2 \mu \mathrm{g} / \mathrm{kg}$ ), the $\mathrm{T}_{1 / 2} \alpha$ value $(0.12$ to $0.15 \mathrm{~h})$ and the $\mathrm{T}_{1 / 2} \beta$ value ( 0.57 to $0.67 \mathrm{~h}$ ) appeared to be greater than those in the previous report. The difference may be due to the assay method for hCRH and/or time points used for pharmacokinetic analysis, although the exact reason remains to be clarified.

Since the pharmacokinetic parameters $\mathrm{T}_{1 / 2}, \mathrm{Vd}$ and $\mathrm{CL}$ were almost constant independent of the dose, and $\mathrm{AUC}_{0}^{\infty}$ increased with good correlation to the dose, it is presumed that the metabolic fate of MCI-028 may not change so much at doses ranging from $33 \mu \mathrm{g}$ to $200 \mu \mathrm{g}$.

Changes in plasma ACTH and cortisol concentrations after the administration of MCI-028 were similar to those in previous studies with synthetic hCRH $[6,11,12]$. And urinary excretion of steroid hormones increased dose-dependently, corresponding to the increase in plasma ACTH and cortisol concentrations. Since significant increases were observed in urinary excretion of free cortisol and 17-OHCS particularly following the administration of MCI-028 at $100 \mu \mathrm{g}$ and more, it is suggested that these parameters can be used as a diagnosis index for the hCRH loading test.

Since there was no adverse reaction other than mild and transient facial warmness and an increase in the heart rate, it is considered that MCI-028 should be quite safe and appeared to be useful when used as a diagnostic drug. 


\section{References}

1. Harris GW (1948) Neural control of the pituitary gland. Physiol Rev 28: 139-179.

2. Vale W, Spiess J, Rivier C, Rivier J (1981) Characterization of a 41-residue ovine hypothalamic peptide that stimulates secretion of corticotropin and beta-endorphin. Science 213: 1394-1397.

3. Shibahara S, Morimoto Y, Furutani Y, Notake M, Takahashi H, Shimizu S, Horikawa S, Numa S (1983) Isolation and sequence analysis of the human corticotropin-releasing factor precursor gene. $E M B O$ J 2: 775-779.

4. Rivier J, Spiess J, Vale W (1983) Characterization of rat hypothalamic corticotropin-releasing factor. Proc Natl Acad Sci USA 80: 4851-4855.

5. Tanaka K, Watabe T, Shimizu N, Hashimoto K, Ibayashi $\mathrm{H}$, Imura $\mathrm{H}$, Irie $\mathrm{M}$, Kageyama $\mathrm{N}$, Kumahara Y, Miyai K, Nakagawa K, Saito S, Shizume K, Tomita A, Yoshinaga K (1983) Effects of synthetic ovine corticotropin-releasing factor (CRF) on plasma ACTH and cortisol in 31 normal human males. Endocrinol Japon 30: 689-695.

6. Fukata J, Nakai $Y$, Imura $H$, Abe $K$, Aono $T$, Demura H, Fujita T, Hibi I, Ibayashi H, Igarashi M, Irie $M$, Izumi $\mathrm{K}$, Kageyama $\mathrm{N}$, Kato $\mathrm{K}$, Kumahara Y, Matsuzaki F, Matsukura S, Miyai K, Mori S, Nakagawa K, Nakajima H, Niimi M, Ogata E, Saito S, Shimizu N, Shizume K, Takahara J, Takakura K, Tomita A, Uozumi T, Wakabayashi I, Yanaihara N, Yoshimi T, Yoshinaga K (1988) Human corticotropin-releasing hormone test in normal subjects and patients with hypothalamic, pituitary or adrenocortical disorders. Endocrinol Japon 35: 491-502.
7. Vale W, Vaughan J, Smith M, Yamamoto G, Rivier J, Rivier C (1983) Effects of synthetic ovine corticotropin-releasing factor, glucocorticoids, catecholamines, neurohypophysial peptides, and other substances on cultured corticotropic cells. Endocrinology 113: 1121-1131.

8. Avgerinos PC, Schurmeyer TH, Gold PW, Tomai TP, Loriaux DL, Sherins RJ, Cutler Jr. GB, Chrousos GP (1986) Pulsatile administration of human corticotropin-releasing hormone in patients with secondary adrenal insufficiency: Restoration of the normal cortisol secretory pattern. $J$ Clin Endocrinol Metab 62: 816-821.

9. Toyama M, Kurimoto F, Kawai A, Fukata J, Nakai Y, Imura H, Iimuro F, Ohno $H$ (1990) Experimental and clinical application of the assay of plasma CRF by radioimmunoassay. Folia Endocrinol Japon 66: 354 (Abstract) (In Japanese).

10. Yamaoka K, Tanigawa Y (1983) Guide to Pharmacokinetic Analysis by a Microcomputer. Nankoudo, Tokyo, Japan (In Japanese).

11. Schurmeyer TH, Avgerinos PC, Gold PW, Gallucci WT, Tomai TP, Cutler Jr. GB, Loriaux DL, Chrousos GP (1984) Human corticotropinreleasing factor in man: Pharmacokinetic properties and dose-response of plasma adrenocorticotropin and cortisol secretion. J Clin Endocrinol Metab 59: 1103-1108.

12. Schopohl J, Hauer A, Kaliebe T, Stalla GK, von Werder K, Muller OA (1986) Repetitive and continuous administration of human corticotropin-releasing factor to human subjects. Acta Endocrinol 112: 157-165. 